\title{
KEJADIAN BALITA STUNTING DI POSYANDU APEL DESA JAMBEARJO KECAMATAN TAJINAN KABUPATEN MALANG
}

\author{
Nunung Ernawati \\ Politeknik Kesehatan RS Dr. Soepraoen Malang \\ E-mail : nunungerna@gmail.com
}

\begin{abstract}
Stunting in children is growth faltering due to accumulation of nutrient insufficiency that lasts from pregnancy to 24 months of age. This situation is exacerbated by the lack of catch-up growth that is adequate, further affecting the physical development of children who are irreversible, to find out the incidence of stunting in children in Posyandu Jambearjo village, the area of the Puskesmas Tajinan Malang district. That research was survey research, was conducted in Posyandu Jambearjo village, the area of Puskesmas tajinan district. The population was used toodlers as many as 98 toodlers. The sample takes with accidental sampling, as many as 58 toodlers. The variable research was insident of stunting and the intruments were antropometric measurements and Z-score calculations. The data was processed to editing, coding, tabulating, then results analyzed using univariate analyzis and presented with pie diagram. The results showed the general characteristics of the respondents that the incidence of stunting in toddlers in the Posyandu was 34 toddlers (59\%) consisting of 14 toddlers (35\%) included in the short stunting category and 20 toddlers (24\%) in the very short stunting category. Based on the results of the study, it is necessary to increase nutrition improvement programs both from the government and non-governmental organizations through the addition of PMT, supplementation and case monitoring.
\end{abstract}

Keywords : Toodlers, stunting insident

\begin{abstract}
Abstrak : Stunting pada anak merupakan growth faltering akibat akumulasi ketidakcukupan nutrisi yang berlangsung lama sejak kehamilan sampai usia 24 bulan. Keadaan ini diperparah dengan tidak terimbanginya kejar tumbuh (catch up growth) yang memadai, selanjutnya berdampak pada perkembangan fisik anak yang bersifat irreversible. Penelitian ini bertujuan untuk mengetahui angka kejadian stunting pada balita di Posyandu Apel Desa Jambearjo wilayah kerja Puskesmas Tajinan kabupaten Malang. Penelitian ini adalah penelitian survey yang dilakukan di Posyandu Apel Desa Jambearjo wilayah kerja Puskesmas Tajinan. Populasi yang digunakan adalah balita di Posyandu Apel sejumlah 98 balita. Sampel penelitian diambil dengan teknik accidental sampling didapatkan sampel penelitian berjumlah 58 balita. variabel penelitian adalah kejadian stunting. Instrumen yang digunakan adalah pengukuran antropometri dan penghitungan Z-score. Hasil dianalisis dengan analisis univariat disajikan dalam bentuk diagram. Hasil penelitian menunjukan karakteristik umum responden diatas menunjukan bahwa angka kejadian stunting pada balita di Posyandu Apel adalah 34 balita (59\%) yang terdiri dari 14 balita (35\%) masuk pada kategori stunting pendek dan 20 balita (24\%) pada kategori stunting sangat pendek. Berdasarkan hasil penelitian, perlu adanya peningkatan program perbaikan gizi baik dari pemerintah maupun swadaya masyarakat melalui penambahan PMT, pemberian suplementasi dan monitoring kasus.
\end{abstract}

Kata Kunci : balita, kejadian stunting

\section{PENDAHULUAN}

Masalah kurang gizi dan stunting merupakan dua masalah yang saling berhubungan. Stunting pada anak merupakan bentuk defisiensi nutrient selama 1000 hari pertama kehidupan. Hal ini akan berdampak pada perkembangan fisik anak yang bersifat irreversible, sehingga akan menyebabkan terhambatnya pertumbuhan fisik, perkembangan mental dan status kesehatan anak (Setiawan, 2018). Hal ini dapat menjadi predictor rendahnya kualitas sumber daya manusia suatu negara. Masalah stunting dianggap menjadi masalah yang berat di suatu negara jika nilai prevalensi berada pada kisaran 30\%-39\%. Rinciannya adalah jumlah balita yang mengalami stunting kategori sangat pendek sebanyak 9.359 dan kategori pendek 20.964 balita. Bayi stunting tersebut tersebar di 33 kecamatan di Kabupaten Malang. Pusat Kesehatan Masyarakat (PKM) Tajinan merupakan salah satu PKM diwilayah Kabupaten Malang dengan jumlah kasus tertinggi balita stunting. Berdasarkan hasil studi pendahuluan didapatkan data bahwa jumlah balita di wilayah kerja PKM tajinan pada tahun 2017 sejumlah 3.443 balita dengan balita pendek sejumlah 607 dan balita sangat pendek 322 , hal ini menunjukkan angka prevalensi stunting di PKM Tajinan adalah $27 \%$. 
Beberapa faktor yang mempengaruhi timbulnya kejadian stunting pada anak yakni faktor langsung seperti asupan nutrisi dan penyakit infeksi, sedangkan faktor tidak langsung yakni pendidikan dan pengetahuan orang tua, pendapatan, distribusi makanan, dan besar keluarga. Faktor ibu seperti postur ibu, jarak kehamilan yang terlalu dekat, pernikahan dini, serta kecukupan gizi saat hamil. Kurangnya nutrisi yang mengandung gizi seimbang saat ibu hamil akan menyebabkan ibu melahirkan bayi lahir dengan berat badan rendah atau bayi lahir dengan panjang badan kurang dari 48 centimeter. Bayi lahir dengan berat badan lahir rendah akan beresiko 4,84 kali lipat untuk menjadi stunting.

Salah satu target Sustainable Development Goals (SDGs) yang termasuk pada tujuan pembangunan berkelanjutan ke-2 yaitu menghilangkan kelaparan dan segala bentuk malnutrisi pada tahun 2030 serta ketahanan pangan. Target yang ditetapkan adalah menurunkan kasus stunting hingga 40\% pada tahun 2025. Negara Indonesia telah menjadi bagian dari SUN Movement (Scalling Up Nutrition), gerakan SUN Movement merupakan upaya memperbaiki gizi masyarakat dan pencegahan setidaknya 20 juta anak agar tidak mengalami pertumbuhan yang terhambat pada tahun 2020, sejalan dengan target global rencana pelaksanaan komprehensif untuk 2025 (WHO, 2014 dalam Atmarita 2015).

Pelaksanaan program di atas diwujudkan dalam bentuk kegiatan gerakan masyarakat sehat melalui pemberian makanan tambahan pada balita, pemberian tablet Fe dan asam folat pada ibu hamil, pemberian taburia dan lain-lain. Namun keberhasilan dari program di atas sangat tergantung dari strategi intervensi pada waktu yang tepat. Penelitian ini memiliki tujuan untuk mengetahui angka kejadian stunting di Posyandu Desa Jambearjo wilayah kerja PKM Tajinan Kabupaten Malang.

\section{METODE PENELITIAN}

desain deskriptif eksploratif yaitu menjelaskan fenomena yang ada. Populasi pada penelitian ini adalah balita yang ada di Posyandu Apel Desa Jambearjo wilayah kerja PKM Tajinan kabupaten Malang sejumlah 98 balita. Sampel penelitian diambil dengan teknik accidental sampling, sehingga didapatkan sampel dengan jumlah 58 balita. Variabel penelitian ini adalah kejadian stunting. Data dikumpulkan dengan instrumen lembar observasi berdasarkan hasil pengukuran antropometri ( $B B$ dan TB) responden kemudian dihitung dengan rumus Z-score. Pengelompokan stunting didapatkan dengan menyesuaikan hasil penghitungan z-score pada tabel ZScore. Pada kasus stunting pemeriksaan yang dibutuhkan yaitu untuk memperoleh indeks antropometri tinggi badan berdasarkan umur (TB/U) (Bardosono. Saptawati, 2017).

Zscore $=\underline{\mathrm{N} \text { individu- } \mathrm{N} \text { median rujukan }}$

N. simpangan baku rujukan

Klasifikasi stunting sebagai berikut :

a. Sangat Pendek: $Z$ score $<-3$

b. Pendek Zscore -3 - Z score $<-2$

c. Normal Z score -2 SD -2 SD

(Kementrian Kesehatan, 2010)

Hasil pengklasifikasian stunting selanjutnya akan diolah dengan analisis univariat dengan rumus prosentase. Data akan disajikan dalam bentuk gambar dan tabel serta dilakukan interpretasi berdasarkan hasil data yang diperoleh. Penelitian ini dilaksanakan dengan memperhatikan prinsip etika penelitian. 


\section{HASIL PENELITIAN}

Berdasarkan hasil penelitian didapatkan data umum dan data khusus responden sebagai berikut:

Diagram 1 Karakteristik Usia Ibu Balita di Posyandu Wilayah Kerja PKM Tajinan Kabupaten Malang

Berdasarkan diagram di atas menunjukan bahwa sebagian besar usia ibu responden

adalah termasuk kategori dewasa awal sejumlah 44 orang ( $76 \%$ ).
Diagram 2 Karakteristik Pendidikan Ibu Balita di Posyandu Wilayah Kerja PKM Tajinan
Kabupaten Malang

adalah termasuk kategori dewasa awal sejumlah 44 orang ( $76 \%$ ).
Diagram 2 Karakteristik Pendidikan Ibu Balita di Posyandu Wilayah Kerja PKM Tajinan
Kabupaten Malang

adalah termasuk kategori dewasa awal sejumlah 44 orang ( $76 \%$ ).
Diagram 2 Karakteristik Pendidikan Ibu Balita di Posyandu Wilayah Kerja PKM Tajinan
Kabupaten Malang
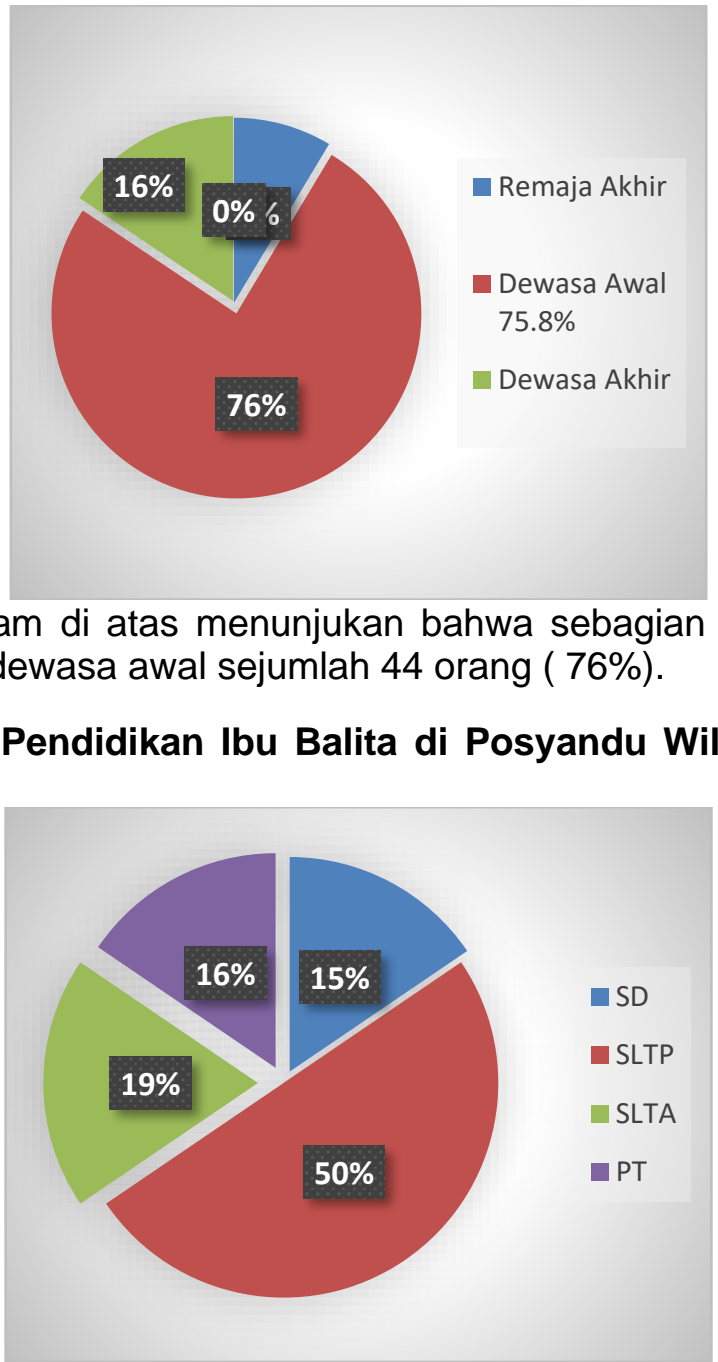

Berdasarkan diagram di atas menunjukan bahwa separuhnya tingkat pendidikan ibu responden adalah SLTP sejumlah 29 ibu (50\%).

\section{Diagram 3 Karakteristik Pendapatan Keluarga Balita di Posyandu Wilayah Kerja PKM Tajinan Kabupaten Malang}

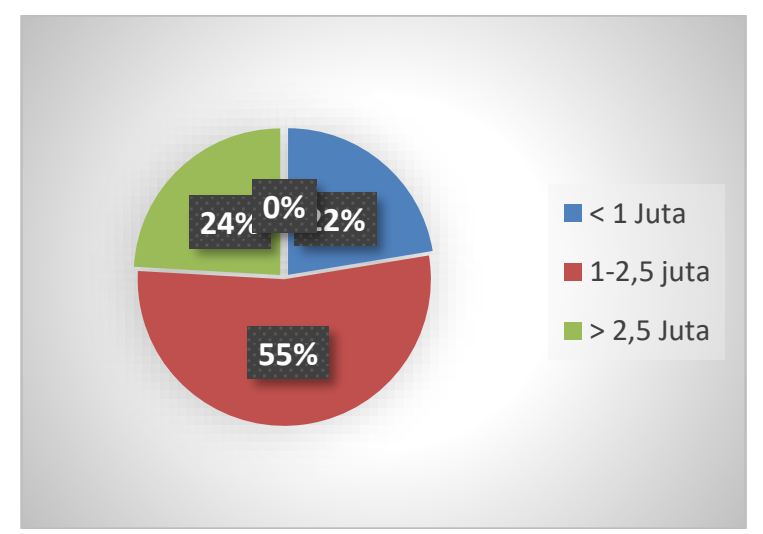

Berdasarkan diagram di atas menunjukan bahwa lebih dari separuhnya pendapatan responden sekitar 1 juta $-2,5$ juta. 
Tabel 1 Distribusi Frekuensi Balita di Posyandu Wilayah PKM Tajinan Kabupaten Malang

\begin{tabular}{|c|c|c|c|}
\hline No. & Karakteristik Umum & Jumlah (f) & Prosentase(\%) \\
\hline \multirow{5}{*}{1.} & Usia & & \\
\hline & 0-12 Bulan & 2 & 3,4 \\
\hline & 13- 36 Bulan & 20 & 34,5 \\
\hline & 37-60 Bulan & 36 & 63,1 \\
\hline & Jumlah & 58 & 100 \\
\hline \multirow{4}{*}{2.} & Jenis Kelamin & & \\
\hline & Laki-laki & 24 & 41,4 \\
\hline & Perempuan & 34 & 58,6 \\
\hline & Jumlah & 58 & 100 \\
\hline \multirow{4}{*}{3.} & Riwayat Sakit & & \\
\hline & Pernah & 28 & 48,3 \\
\hline & Tidak pernah & 30 & 51,7 \\
\hline & Jumlah & 58 & 100 \\
\hline \multirow{4}{*}{4.} & Pemberian ASI Eksklusi & & \\
\hline & $\mathrm{Ya}$ & 41 & 48,3 \\
\hline & Tidak & 17 & 29,3 \\
\hline & Jumlah & 58 & 100 \\
\hline \multirow{5}{*}{5.} & Riwayat Kelahiran & & \\
\hline & Pre Term & 12 & 20,7 \\
\hline & Aterm & 42 & 72,4 \\
\hline & Post Term & 4 & 6,9 \\
\hline & Jumlah & 58 & 100 \\
\hline \multirow{6}{*}{6.} & Status Gizi & & \\
\hline & Baik & 27 & 46,5 \\
\hline & Kurang & 27 & 46,5 \\
\hline & Buruk & 3 & 5,2 \\
\hline & Lebih & 1 & 1,7 \\
\hline & Jumlah & 58 & 100 \\
\hline
\end{tabular}

Berdasarkan tabel di atas menunjukan bahwa balita yang di Posyandu wilayah kerja PKM Tajinan lebih dari setengahnya berusia 37-60 bulan sejumlah $64,1 \%$ dengan jenis kelamin lebih dari separuhnya $58,6 \%$ adalah perempuan, lebih dari separuhnya balita tidak memiliki riwayat sakit sejumlah 51,7\%, hampir setengahnya balita diberikan ASI eksklusif 48,3\%, untuk riwayat kelahiran lebih dari setengahnya $72,4 \%$ memiliki riwayat kelahiran aterm

Diagram 4 Kejadian Stunting Pada Balita Di Posyandu Desa jambearjo Wilayah Kerja PKM Tajinan Kabupaten Malang

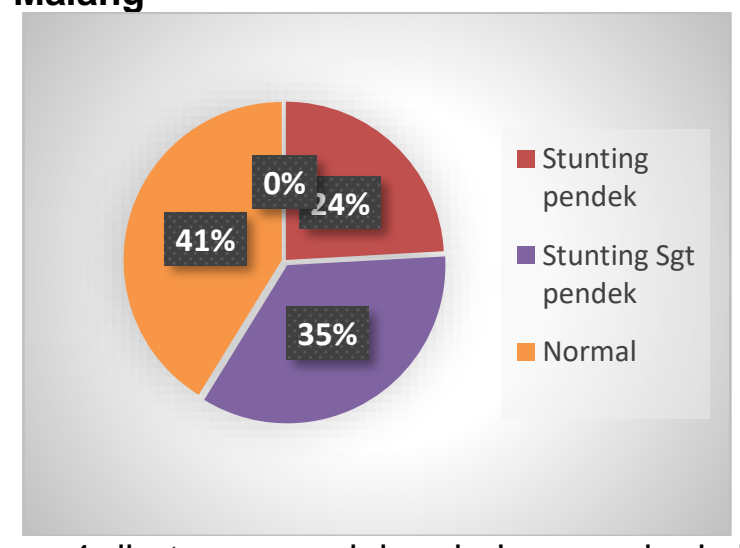

Berdasarkan diagram 4 di atas menunjukan bahwa angka kejadian stunting pada balita 
di posyandu adalah 34 balita (59\%) yang terdiri dari 14 balita $(35 \%)$ masuk pada kategori stunting pendek dan 20 balita (24\%) pada kategori stunting sangat pendek.

\section{PEMBAHASAN}

Hasil penelitian di atas didukung oleh data dari karakteristik ibu balita antara lain; pendidikan ibu balita $65 \%$ adalah pendidikan dasar yaitu 50\% SLTP dan $15 \%$ $\mathrm{SD}$, sedangkan dari usia ibu balita sebagian besar menunjukkan usia muda $84 \%$ yaitu kategori dewasa awal $76 \%$ dan kategori usia remaja akhir 8\%. Data sosial ekonomi ibu balita didukung oleh pendapatan keluarga sebagian besar $76 \%$ pendapatan $<2,5$ juta.

\section{Menurut Notoatmodjo}

(2012)

menyatakan bahwa pengetahuan merupakan hasil dari tahu dan ini terjadi setelah seseorang melakukan penginderaan. Tingkat pendidikan mempengaruhi proses belajar, semakin tinggi tingkat pendidikan seseorang tersebut semakin mudah menerima informasi.

Status sosial ekonomi seseorang akan menentukan tersedia tidaknya fasilitas yang diperlukan untuk keberlangsungan kegiatan tertentu sehingga status sosial ekonomi ini akan mempengaruhi pengetahuan. Usia mempengaruhi daya tangkap dan daya nalar seseorang, namun menurut Agus (2013) menyatakan bahwa IQ seseorang akan menurun cukup cepat dengan bertambahnya usia.

Stunting adalah kondisi gagal tumbuh akibat kekurangan gizi kronis selama 1.000 hari pertama kehidupan anak.Kekurangan gizi terjadi sejak bayi dalam kandungan dan pada masa awal setelah bayi lahir, tetapi kondisi stunting baru nampak setelah anak berusia 2 tahun (Ramayulis et al., 2018).

Data hasil penelitian dan teori diatas saling mendukung, karena dari data hasil penelitian jumlah kejadian stunting 34 balita ( $59 \%$ ) ini di desa Jambearjo wilayah PKM Tajinan sesuai dengan angka kejadian stunting di Kabupaten Malang yang masih diatas 20\% hal ini disebabkan karena penyebab timbulnya kasus stunting sangat kompleks. Kondisi anak pendek/stunting sangat erat dengan kemiskinan dan atau kondisi sosiodemografi menengah ke bawah, yang dapat mempengaruhi individu dalam penyediaan bahan pangan, disamping itu pendidikan yang rendah sangat memberikan kontribusi terhadap tinggi rendahnya pengetahuan seseorang, dan ditunjang dari status sosioekonomi yang kurang memadai. Usia ibu yang terlalu muda dapat mempengaruhi praktik pengasuhan anak yang kurang baik. Praktik budaya masyarakat Indonesia yang masih kontradiksi dengan program kesehatan masih marak dilakukan, sehingga memungkinkan untuk mendukung timbulnya stunting.

Selain data di atas, kejadian stunting juga dapat didukung oleh data umum balita yaitu jumlah balita yang balita dengan riwayat tidak diberikan ASI ekslusif sejumlah 17 balita (29,3\%), riwayat kelahiran pre term $12(20,7 \%)$ dan post term 4 $(6,9 \%)$, status gizi kurang 27 balita $(47 \%)$ dan gizi buruk sejumlah 3 balita (5\%).

Stunting (kerdil) adalah kondisi dimana balita memiliki panjang badan atau tinggi badan yang kurang dibandingkan dengan umurnya (Atmarita, Trihono dkk. 2015). Kejadian stunting dipengaruhi juga oleh faktor anak yang dapat mempengaruhi timbulnya stunting adalah praktik pengasuhan yang kurang baik, riwayat pemberian ASI, riwayat infeksi, tumbuh kembang balita, pengetahuan orang tua dan pendapatan. Percepatan tumbuh kembang balita dipengaruhi oleh banyak faktor seperti usia, usia yang terlalu muda dapat mempengaruhi kemampuan individu dalam melakukan tindakan, riwayat sakit atau kondisi kesehatan saat dilakukan skrining dapat mempengaruhi hasil skrining, ditunjang juga dari faktor lain seperti kondisi gagal tumbuh dan hambatan pada praktik pengasuhan seperti minimalnya stimulasi perkembangan pada anak, yang disebabkan karena kurangnya pengetahuan ibu.

\section{KESIMPULAN DAN SARAN}

Berdasarkan hasil penelitian
didapatkan kejadian stunting lebih dari
separuh populasi penelitian yaitu $59 \%$ ( 34
balita). Hal ini menunjukan bahwa masih
banyak kasus gizi buruk kronis yang
membutuhkan perhatian dan perawatan
sehingga petugas kesehatan dan
masyarakat harus bekerjasama dalam
penanganan kasus stunting ini baik melalui


lintas program maupun lintas sektoral. Program pengentasan kasus stunting harus diprioritaskan melalui pemberian makanan

\section{DAFTAR PUSTAKA}

Atmarita. Trihono dkk. ( 2015). Pendek (Stunting) di Indonesia, Masalah dan Solusinya. Jakarta, Balitbangkes , 2015

Atmarita, ( 2012). Masalah Anak Pendek di Indonesia dan Implikasinya terhadap kemajuan negara. Jurnal Gizi Indonesia. Vol 35. No 2 tahun 2012

Bardosono. Saptawati,( 2017). Penilaian Status Gizi Balita ( Antropometri). (2018). Situasi Balita Pendek ( Stunting di Indonesia. Buletin Data dan Jendela Informasi Kesehatan, ISSN 2088-270 X. Semester I, Tahun 2018

Devi, M. (2012). Analisis Faktor -Faktor Yang Berpengaruhi Terhadap Status Gizi Balita Dipedasaan. Jurnal Teknoloi dan Kejuruan. Volume 33. Issue 2 tahun 2012

Ernawati, F dkk. (2011). Studi Longitudinal faktor Resiko Terjadinya Balita Stunting.

Ernawati, F dkk.( 2012). Studi Longitudinal Faktor Resiko Terjadinya Stunting Pada Anak Baduta (Penelitian tahun ke-2) . Pgi Terapan Kesehatan dan Epidemiologi Klinik Badan Litbangkes RI tambahan, pemberian suplementasi Zink, vitamin A dan perbaikan sanitasi.

Eko Setyawan, Rizanda Machmud.(2018). Faktor-Faktor Yang Berhubungan Dengan Kejadian Stunting Pada Anak usia 24-59 Bulan di wilayah kerja Puskesmas Andalas. Jurnal FK Andalas

Kementrian Kesehatan RI. (2013) PokokPokok Hasil Riskesdas Indonesia 2013. Jakarta: Kementrian kesehatan RI.

Ni'mah, Khoirun, dkk (2015). Faktor Yang Berhubungan Dengan Kejadian Stunting pada Balita. Media Gizi Indonesia, Vol 10 No 1 JanuariJuni 2015.

Notoadmojo.S.(2011). Kesehatan Masyarakat, Ilmu dan Seni. Rineka Cipta. Jakarta 2011.

Ramayulis, R. et all (2018). Stop Stunting Dengan konseling Gizi, Jakarta : Penebar Plus 